\title{
LOUVRED NOISE BARRIER FOR TRAFFIC NOISE REDUCTION
}

\author{
TOMAS ASTRAUSKAS ${ }^{2 *}$, PRANAS BALTRE்NAS ${ }^{1}$, \\ TOMAS JANUŠEVIČIUS ${ }^{1}$, RAIMONDAS GRUBLIAUSKAS ${ }^{2}$ \\ ${ }^{1}$ Research Institute of Environmental Protection, \\ Vilnius Gediminas Technical University, Vilnius, Lithuania \\ ${ }^{2}$ Dept of Environmental Protection and Water Engineering, \\ Vilnius Gediminas Technical University, Vilnius, Lithuania
}

Received 7 August 2020; accepted 24 November 2020

\begin{abstract}
Environmental issues near roads become more and more important in our society daily life. One of the most critical environmental issues is traffic noise. The present paper study louvred noise barrier designed by authors. The louvred noise barrier provides sound attenuation while allowing airflow and sunlight through it. Since the airflow resistance of the barrier is low, it requires a shallow foundation compared to conventional noise barriers. The sound attenuation performance of the louvred noise barrier was tested experimentally in a sound transmission chamber. Airflow resistance simulated using a computational fluid dynamics model. The simulation and experimental study were done with different louvred noise barrier setup: change of louvre blade angle and sound-absorbing material thickness. The results showed potential for future development for the field testing. Sound attenuation was highest in $2500 \mathrm{~Hz}$ and $3150 \mathrm{~Hz}$ octave frequency bands. Depending on the louvred barrier
\end{abstract}

* Corresponding author. E-mail: tomas.astrauskas@vilniustech.lt

Tomas ASTRAUSKAS (ORCID ID 0000-0003-0044-371X)

Pranas BALTRĖNAS (ORCID ID 0000-0003-3551-9462)

Tomas JANUŠEVIČIUS (ORCID ID 0000-0002-8093-7885)

Raimondas GRUBLIAUSKAS (ORCID ID 0000-0002-8625-9333)

Copyright (C) 2021 The Author(s). Published by RTU Press

This is an Open Access article distributed under the terms of the Creative Commons Attribution License (http://creativecommons.org/licenses/by/4.0/), which permits unrestricted use,

distribution, and reproduction in any medium, provided the original author and source are credited. 
setup, sound attenuation was up to $28 \mathrm{~dB}(\mathrm{~A})$ in mentioned frequency bands. The equivalent sound pressure level reduced up to $17 \mathrm{~dB}(\mathrm{~A})$. The results showed that an increase in the louvre blade angle increases sound attenuation and increases airflow resistance.

Keywords: airflow, louvred barrier, mineral wool, noise barrier, soundabsorbing materials, sound attenuation.

\section{Introduction}

Traditionally noise is described as any intrusive or disruptive sound (Monsefi et al., 2011). A sound becomes intrusive when it disturbs people everyday activities, such as sleep, conversations or deteriorates the quality of life (Baltrènas et al., 2010; Gražulevičienė \& Bendokienė, 2009; Zavadskas et al., 2009). As reported by the World Health Organization, $20 \%$ of the European Union population is exposed to noise exceeding $65 \mathrm{~dB}(\mathrm{~A})$, and $30 \%$ of the population exposed to noise exceeding $55 \mathrm{~dB}(\mathrm{~A})$. Extended exposure to such noise level may cause health problems. The most frequent noise-related diseases are sleep disorders, cardiovascular and mental diseases. People who regularly exposed to $85-90 \mathrm{~dB}(\mathrm{~A})$ noise at factories or industrial premises are at risk of progressing loss of hearing or hyperacusis (World Health Organization, 2011).

One of the solutions to reduce environmental noise pollution is to use noise barriers. Their shape could classify noise barriers (Figure 1) and the materials used. The barriers, which have perforated plates with absorbing material inside classified as absorptive, are made of brick or plastics classified as purely reflective-noise barriers classified using those parameters (Table 1).

One of the most critical parameters of traditional noise barrier design is the shape. Different shapes of barrier provide better sound screening geometrically. Several studies are done to test the performance of different shape of noise barriers. Such studies focus on inclination

Table 1. Classification of various noise barriers (Yoon \& Pyo, 2019)

\begin{tabular}{|c|c|c|c|}
\hline Shape & Material & $\begin{array}{l}\text { Type regarding } \\
\text { sound absorption }\end{array}$ & Fillers \\
\hline plane, vertical & metal & no absorption & mineral wool \\
\hline plane, inclined & concrete & integrated & chip wood \\
\hline plane, curved & ceramic bricks & absorption & clay or other \\
\hline plane, bent & wood or board & additional absorption & ceramic grains \\
\hline \multirow[t]{2}{*}{ embankment } & transparent & & plastic or rubber \\
\hline & glass or plastic & & foam \\
\hline
\end{tabular}




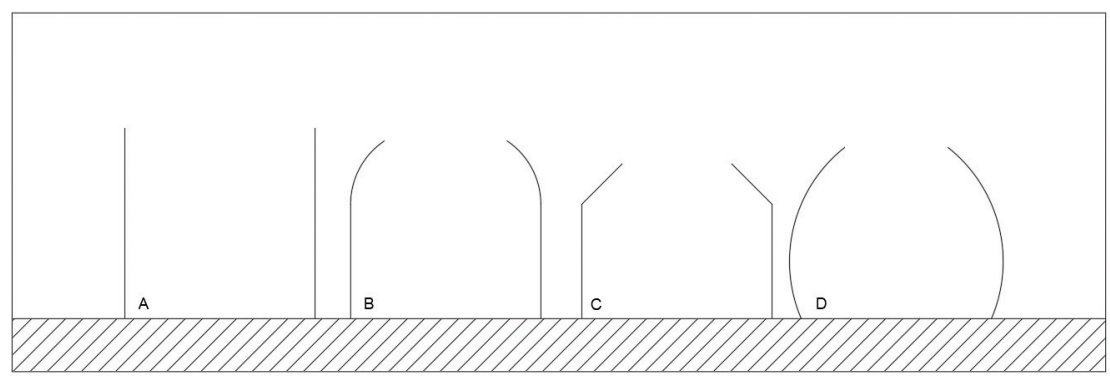

Note: A - vertical, B - curved, C - inclined, D - bent.

Figure 1. Different shapes of noise barriers

angles of noise barrier rooftop shield (Figure 1, C) (Defrance \& Jean, 2003; Venckus et al., 2012; Voropayev et al., 2017). Such devices on noise barriers are needed to change the sound diffraction wavefield.

Recently designs with air gaps become more attractive in the research of noise barrier development. Several designs of noise barriers with air gaps have been proposed. Noise barriers with air gaps could be attractive to constructors because it requires a shallow foundation since airflow resistance of such barriers are close to zero (Dimitrijević et al., 2019). Often such systems use sonic crystals to scatter the sound energy (Figure 2). Studies show that sound barriers using sonic crystals attenuate sound levels up to $16 \mathrm{~dB}(\mathrm{~A})$. However, the reported results do not show the broadband attenuation (Dimitrijević et al., 2019). The distinct design sonic crystal noise barrier reaches up to $25 \mathrm{~dB}(\mathrm{~A})$ (Sánchez-Pérez et al., 1998). Such a noise barrier is designed with channels inside the columns to create resonant elements (Radosz, 2019).

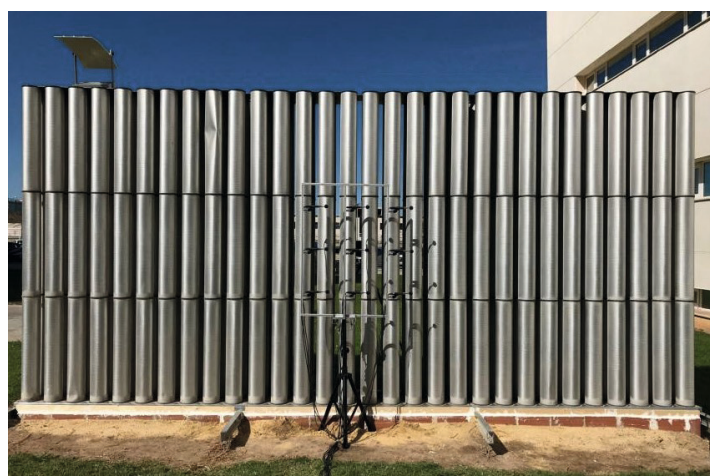

Figure 2. Noise barrier with air gaps (Dimitrijević et al., 2019) 
Sound-absorbing materials coverings in such noise barriers usually used to achieve more broadband sound attenuation (Engel, 2014; GarcíaChocano \& Sánchez-Dehesa, 2013; Romero-García et al., 2009; Umnova et al., 2006).

Louvred noise barriers used as a structural element that controls noise and, at the same time, enables the airflow and lighting through the construction while attenuating the sound (Lee et al., 2020). Such noise barriers can be used in facades of buildings, as sound-attenuating jackets for engineering equipment that needs ventilation, e.g., air conditioners or near roads. Louvred barriers may also be used as a noise barrier on highways instead of traditional noise barriers. Compared to commonly used non-transparent shields, louvred noise barriers increase the flow of natural light onto the road surface and allow the travellers to see the surrounding areas while travelling (Viveiros et al., 2002; Watts et al., 2001). Louvred barriers could also be used as an alternative to currently commonly used traditional noise barriers. The noise barrier effectiveness mainly depends on its height, the shape of the top and the place of installation (Duhamel, 2006; Naderzadeh et al., 2011; Venckus et al., 2012).

This article aims to propose a design for a louvred noise barrier with low airflow resistance. The paper organised as follows: in Section 1, the design of the louvred noise barrier and testing methods presented; in Section 2, the results of the study presented; in Section 3, the discussion and the conclusions presented.

\section{Louver design and testing methods}

Figure 1 presents the designed louvred noise barrier. The presented design provides high ventilation while diffracting the sound waves in the desired direction. The tested louvred barrier dimensions are $1.0 \mathrm{~m} \times 1.0 \mathrm{~m}$. A barrier made of 7 steel blades of $3 \mathrm{~mm}$ thickness equally spaced at $120 \mathrm{~mm}$ distances. The drawings with the indicated dimensions presented in Figure 3.

Every sound attenuation test has been done with louvre blades in a horizontal position and changing tilt angle from $0^{\circ}$ to $45^{\circ}$ with a step of $15^{\circ}$ (Figure 4). All louvre blades tilted in parallel.

The sound absorption of such a barrier is linked to the sound absorption of mineral wool and the air permeability of the barrier. Since it is well-known that mineral wool shows high sound absorption, there was done several computational fluid dynamics (CFDs) simulation runs. The simulation investigates the correlation between air permeability and sound reduction of such barrier using "SimScale" modelling 

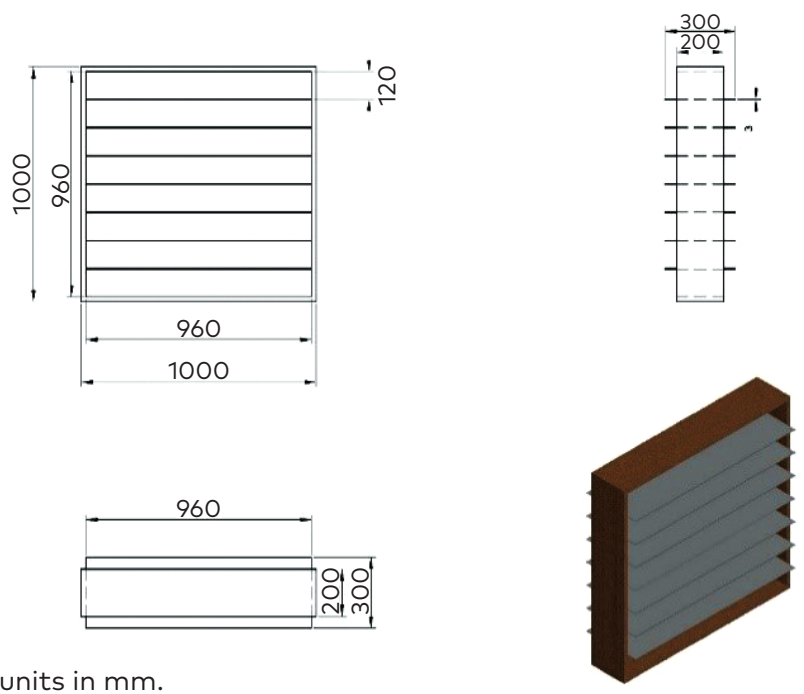

Note: units in $\mathrm{mm}$.

Figure 3. The design of the louvred noise barrier for laboratory sound attenuation tests

software. CFD simulation model was incompressible and steady-state flow.

The testing was done using different thickness mineral wools:

- covered with mineral wool on both sides: density $40 \mathrm{~kg} / \mathrm{m}^{3}$, thickness $10 \mathrm{~mm}$;

- covered with mineral wool on both sides: density $40 \mathrm{~kg} / \mathrm{m}^{3}$, thickness $20 \mathrm{~mm}$;

- covered with mineral wool on both sides: density $40 \mathrm{~kg} / \mathrm{m}^{3}$, thickness $30 \mathrm{~mm}$.

The transmission chamber used to determine the designed louvred noise barrier sound attenuation (Figure 5). The transmission chamber
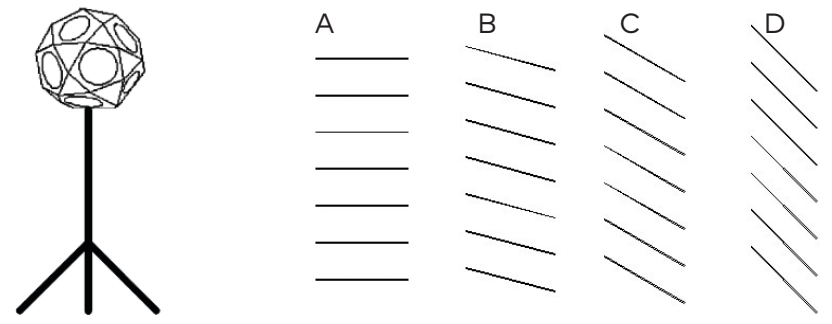

Note: $\mathrm{A}-0^{\circ} ; \mathrm{B}-15^{\circ}, \mathrm{C}-30^{\circ}, \mathrm{D}-45^{\circ}$.

Figure 4. Tilting positions of louvred barrier blades in measurements 


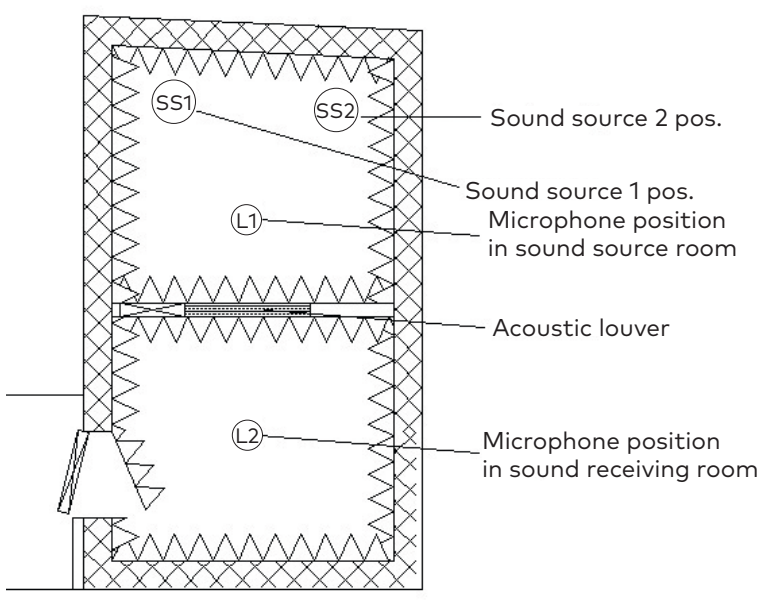

Figure 5. Equipment and tested louvre positions in the chamber

made of two rooms separated by an opening where the test specimen placed. The sound receiving room is semi-anechoic. The connecting partition of chamber rooms is soundproofed to reduce the indirect noise transmission (i.e., not through the opening where the test specimens are placed) and minimise the background noise sounds in the noise attenuation chamber. A louvred barrier tightly fixed in the wall opening for the test sample, with all edges insulated with soundproofing tape. Due to the limitations of the chamber, the lowest measured frequency was $500 \mathrm{~Hz}$.

The tests were done following the methodology described in ISO 10140-2:2010 Acoustics Laboratory measurement of sound insulation of building elements Part 2: Measurement of airborne sound insulation. Sound attenuation was measured from $500 \mathrm{~Hz}$ to $8000 \mathrm{~Hz}$ using 1/3 octave band filtering (International Organization for Standardization, 2010).

$$
D=L_{1}-L_{2}, \mathrm{~dB}(\mathrm{~A})
$$

where $D$ is the sound level difference between chamber rooms, $\mathrm{dB}(\mathrm{A})$; $L_{1}$ is the sound level in the acoustic chamber room where the sound source located, $\mathrm{dB}(\mathrm{A}) ; L_{2}$ is the sound level in the other room of the acoustic chamber behind the louvred noise barrier, $\mathrm{dB}(\mathrm{A})$.

The experimental setup consists of two $1.27 \mathrm{~cm}(0.5 \mathrm{in})$ microphones and a sound source. White noise used for sound attenuation testing. The sound source and one microphone placed in the first room the source room), the second microphone is placed in the other room (sound receiving room) and separated from the sound source by a louvred noise barrier. The sound attenuation measurements were done using 
two sound source positions and one position for each microphone (Figure 3). Microphone positions limited due to possible adverse effects of interferences of reflected waves in the rooms. The averaging was done of 5 measurements with each $3 \mathrm{~min}$ long. Measurements were done with four different tilting angles of blades of a noise barrier regarding the sound source (Figure 2).

\section{Results}

At first, a sound attenuation test done with louvred barrier blades without any sound-absorbing material. The purpose of this test was to determine how much noise can be reduced with this type of barrier by merely diverting the sound by louvred barrier blades.

Figure 6 illustrates that sound insertion loss depends on the louvre blade angle in the frequency range from $500 \mathrm{~Hz}$ to $8000 \mathrm{~Hz}$. The frequency range from $500 \mathrm{~Hz}$ to $630 \mathrm{~Hz}$ reduces from $1 \mathrm{~dB}(\mathrm{~A})$ to $6 \mathrm{~dB}(\mathrm{~A})$ depending on the blade angle. The sound level reduces from $1 \mathrm{~dB}(\mathrm{~A})$ to $5 \mathrm{~dB}(\mathrm{~A})$ in the frequency range from $630 \mathrm{~Hz}$ to $1600 \mathrm{~Hz}$. The sound level reduces from $1 \mathrm{~dB}(\mathrm{~A})$ to $11 \mathrm{~dB}(\mathrm{~A})$ in the frequency range from $2 \mathrm{kHz}$ to $8 \mathrm{kHz}$. The diagram shows that the higher sound attenuation achieved when louvre blades tilted at a $30^{\circ}$ or $45^{\circ}$ angle.

The computational fluid dynamic simulation shows a correlation with sound attenuation results. A relative increase of energy $(k)$ is presented in computational fluid dynamic modelling figures while airflow conditions are applied. Where is from $0 \mathrm{~m}^{2} / \mathrm{s}^{2}$ to $50 \mathrm{~m}^{2} / \mathrm{s}^{2}$. The highest air energy growth found when blades were tilted at $30^{\circ}$ (Figure 7, C). Similar results found during the experimental sound attenuation study.

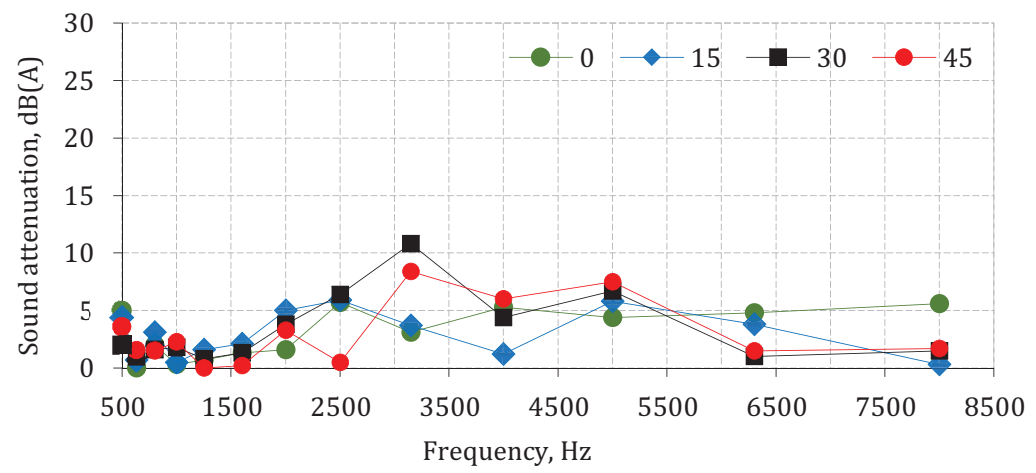

Figure 6. Test results with blades without sound any absorbing material 

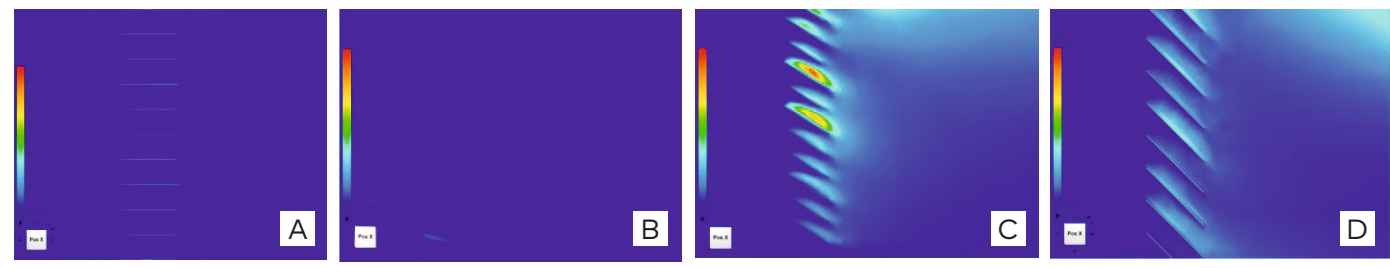

Note: $\mathrm{A}-\mathrm{O}^{\circ} ; \mathrm{B}-15^{\circ} ; \mathrm{C}-30^{\circ} ; \mathrm{D}-45^{\circ}$.

Figure 7. Energy growth per area of the barrier without sound-absorbing material

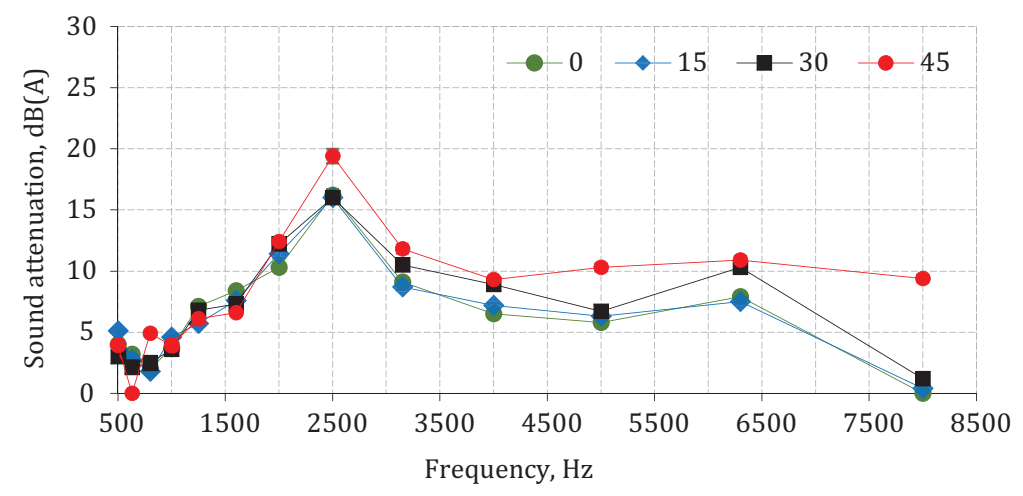

Figure 8. Test results with blades covered with $10 \mathrm{~mm}$ thickness of mineral wool on both sides

Figure 8 shows the sound attenuation of the louvre when its blades covered with a $10 \mathrm{~mm}$ thickness of mineral wool. Due to the wavelength of lower frequency sound waves, sound attenuation efficiency is noticeably lower in lower frequencies, and the difference between
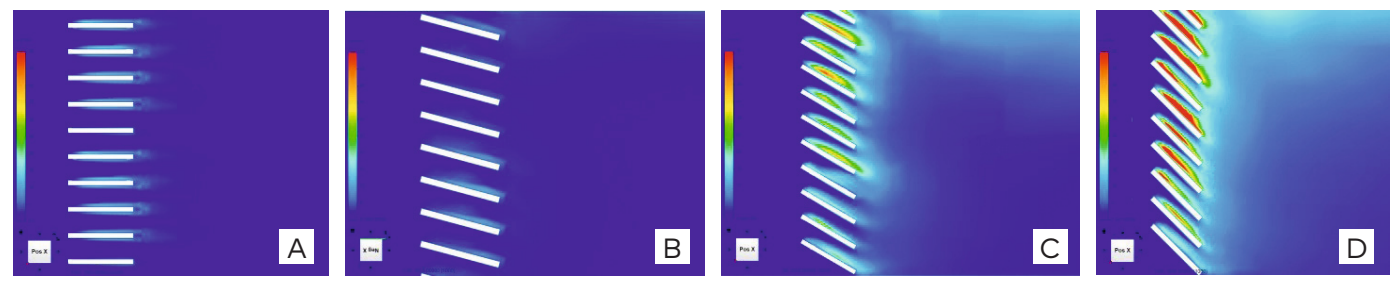

Note: $\mathrm{A}-\mathrm{O}^{\circ} ; \mathrm{B}-15^{\circ} ; \mathrm{C}-30^{\circ} ; \mathrm{D}-45^{\circ}$.

Figure 9. Energy growth per area of barrier with $10 \mathrm{~mm}$ thickness of mineral wool 


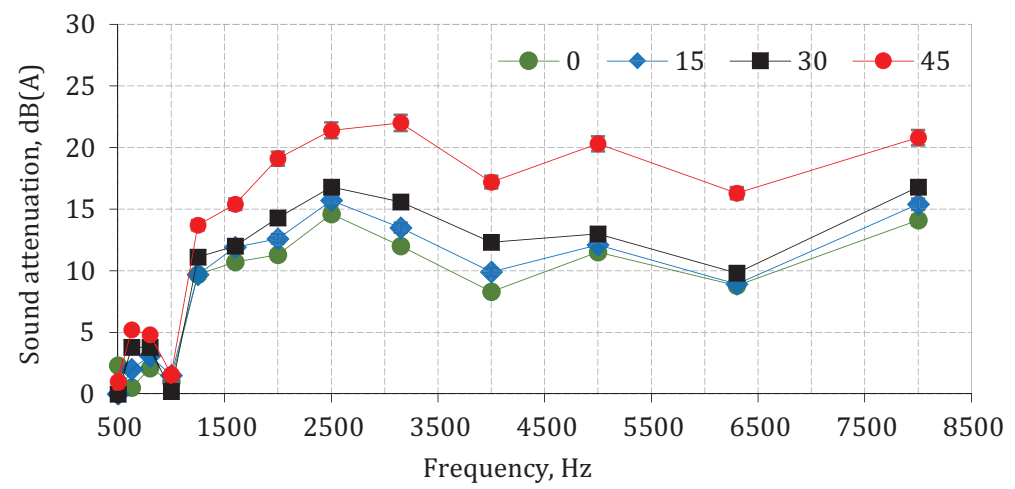

Figure 10. Test results with blades covered with $20 \mathrm{~mm}$ thickness of pressed mineral wool on both sides

barrier setups is insignificant (from $500 \mathrm{~Hz}$ to $2000 \mathrm{~Hz}$ ). The sound level attenuation values reach from $5 \mathrm{~dB}(\mathrm{~A})$ to $19 \mathrm{~dB}(\mathrm{~A})$ in the frequency range from $1250 \mathrm{~Hz}$ to $8000 \mathrm{~Hz}$ when louvre blades tilted at a $45^{\circ}$ angle. Figure 8 shows that with the increase in blade tilting angle, louvre barrier sound attenuation increases.

The computational fluid dynamic simulation shows a correlation with sound attenuation results. The highest energy growth was found then blades was tilted at $45^{\circ}$ (Figure 9, D). The sound attenuation experimental results show that the highest sound reduction gained at a $45^{\circ}$ barrier setup. Therefore $0^{\circ}$ and $15^{\circ}$ setup showed similar results after simulation and experimental study. The increase of airflow energy in those tilting angles are similarly low. A similar tendency also applies to sound attenuation results.

When barrier blades covered with a $20 \mathrm{~mm}$ thickness of pressed rockwool, sound attenuation is higher than the test results of a $10 \mathrm{~mm}$
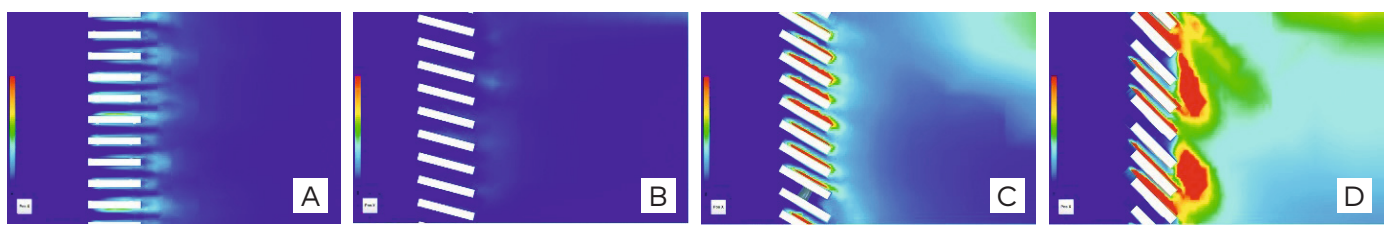

Note: $\mathrm{A}-\mathrm{O}^{\circ} ; \mathrm{B}-15^{\circ} ; \mathrm{C}-30^{\circ} ; \mathrm{D}-45^{\circ}$.

Figure 11. Energy growth per area of barrier with $20 \mathrm{~mm}$ thickness of mineral wool 


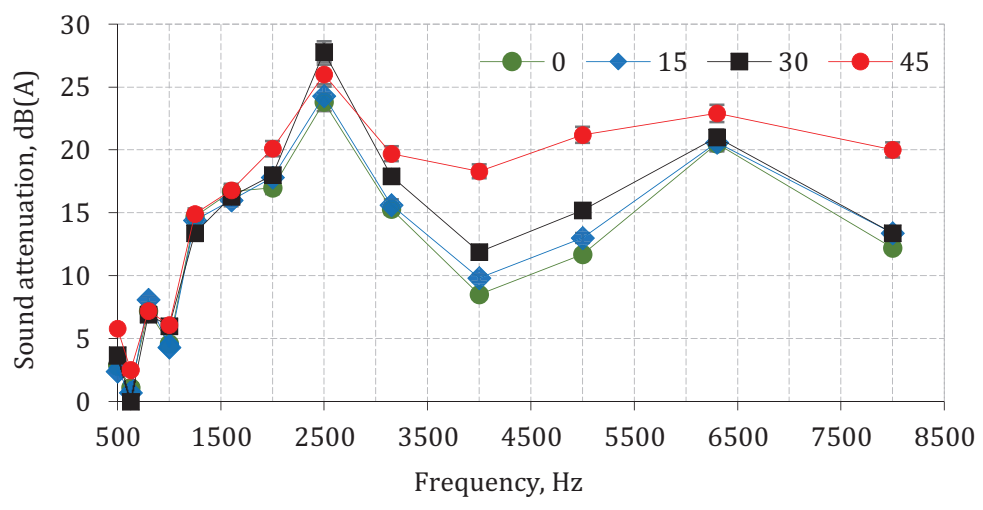

Figure 12. Test results when louvre blades covered with $30 \mathrm{~mm}$ thickness of pressed rockwool on both sides

thick mineral wool setup. In this case, sound attenuates in a wider frequency range from $1250 \mathrm{~Hz}$ to $8000 \mathrm{~Hz}$ (from $8 \mathrm{~dB}(\mathrm{~A})$ to $22 \mathrm{~dB}(\mathrm{~A})$ attenuation). As in the previous case, at lower frequencies, sound attenuations stay similar with blade tilting angle (from $500 \mathrm{~Hz}$ to $1000 \mathrm{~Hz}$ ). The influence of the tilting angle is noticeable from $1250 \mathrm{~Hz}$. Sound attenuation increases with blade angle inclination.

Figure 11 shows the energy growth per area increase with louvre blade inclination. The highest energy growth was found, then the blades were tilted at $45^{\circ}$ (Figure 11, D), which means that this setup provides the lowest air permeability. The simulation results correlate with sound attenuation results.

In Figure 12, the results of sound attenuation using $30 \mathrm{~mm}$ thick mineral wool presented. Sound attenuation increased compared to other tested cased using this setup. As in previously presented cases, sound attenuation increases with blade angle. Peak attenuation gained at
Tomas Astrauskas, Pranas Baltrènas,

Tomas Januševičius,

Raimondas

Grubliauskas

Louvred Noise Barrier for Traffic Noise

Reduction
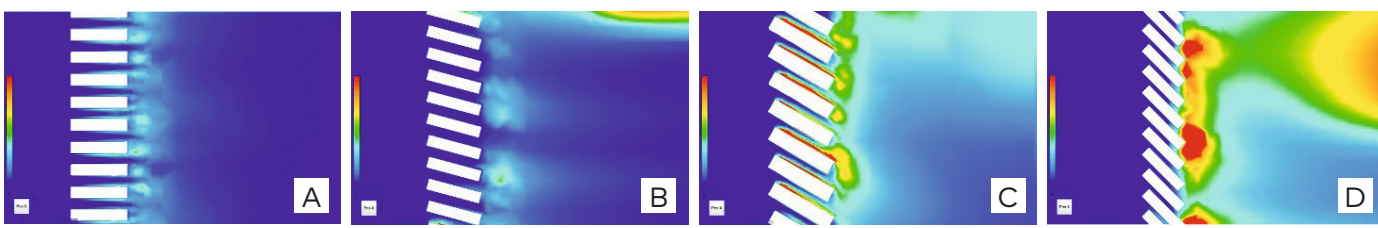

Note: $\mathrm{A}-\mathrm{O}^{\circ} ; \mathrm{B}-15^{\circ} ; \mathrm{C}-30^{\circ} ; \mathrm{D}-45^{\circ}$.

Figure 13. Energy growth per area of barrier with $30 \mathrm{~mm}$ thickness

of mineral wool 
$2500 \mathrm{~Hz}$ frequency (attenuation varies from $24 \mathrm{~dB}(\mathrm{~A})$ to $28 \mathrm{~dB}(\mathrm{~A})$ ). Using this setup wider frequency range has no influence on lower frequencies than other setups (from $500 \mathrm{~Hz}$ to $2000 \mathrm{~Hz}$ ).

Figure 13 shows the energy growth per area increase with louvre blade inclination. The highest energy growth was found then blades was tilted at $45^{\circ}$ (Figure 13, D), which means that this setup provides the lowest air permeability. The simulation results correlate with sound attenuation results. Comparing to all CFD simulation runs, it is noticeable that energy air energy growth increases with the thickening mineral wool layer. Such phenomena occur because shrinking air gap when increasing the thickness of mineral wool.

Figure 14 illustrates the drop in equivalent sound level $\left(L_{A, e q}\right)$ when louvre blades tilted at different angles. In most cases, the best sound attenuation results obtained when louvre blades tilted at a $45^{\circ}$ angle, irrespective of the coating of the blades. The best sound attenuation result $(17.3 \mathrm{~dB}(\mathrm{~A}))$ achieved when louvre blades are covered with a $30 \mathrm{~mm}$ thickness of mineral wool and tilted at a $45^{\circ}$ angle. The worst sound attenuation $(1.8 \mathrm{~dB}(\mathrm{~A}))$ was observed when louvre blades were without sound-absorbing materials and tilted at a $45^{\circ}$ angle.

In the studies of other authors who used similar design louvred barriers, best results obtained when blades tilted at $45^{\circ}$ and $60^{\circ}$ angles (Januševičius, 2011; Matsumoto et al., 2004). Other researchers have also analysed sound attenuation by louvred barriers of other designs. At low and average frequencies from $100 \mathrm{~Hz}$ to $1000 \mathrm{~Hz}$, sound attenuations differed insignificantly, irrespective of the louvred barrier blade tilt angle. Such a phenomenon occurs because there is only the effect of a mass layer in these frequencies. Other authors in their studies stated

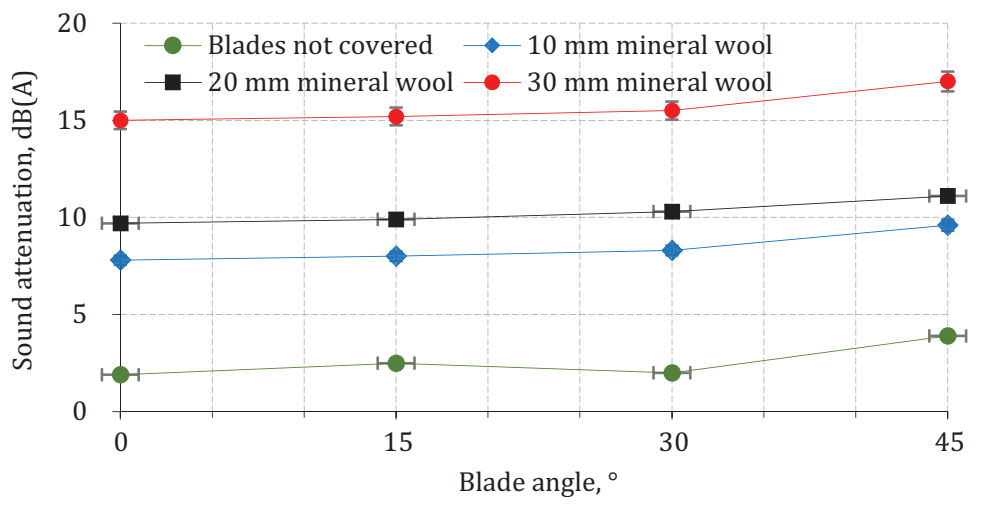

Figure 14. Comparison of the change in equivalent sound pressure level 
that a louvre blade tilt angle does not influence the obtained results in these frequencies (Januševičius, 2011; Matsumoto et al., 2004; Viveiros, 1998). At higher frequencies, sound attenuation caused by the absorption of sound-absorbing material and the diffraction of waves (Viveiros, 1998). Compared to other studies regarding open barriers, this design of barrier provides more broadband sound attenuation.

The limitation of this study is that such a louvred barrier design is not directly applicable for use by the roads due to humidity and possible rain effects on mineral wool. Materials with good sound absorption properties are recommended in future development because the principal barrier effectiveness comes from sound absorption phenomena. Based on laboratory tests presented, a live scale barrier could be developed and tested. For use near roads and railways, such a louvred barrier design could be used as a top part of the barrier to increase lighting on-road and decrease overall airflow resistance. Another possible way to use a louvred barrier is on viaducts. Therefore, it provides low airflow resistance, and it would not increase loads on construction significantly. In future studies, sound-absorbing materials that are more resistant to atmosphere conditions required. Due to barrier construction design, this barrier is almost non-existent to air, making the foundation cheaper than conventional noise barriers.

\section{Conclusions}

In this study, the design of an innovative open, louvred noise barrier proposed. After an experimental and computational fluid dynamic simulation study, found that sound attenuation increases with airflow resistance. The study shows that increasing blade angle increase sound attenuation as well as airflow resistance.

1. It was found that sound attenuation increases by increasing the blade inclination angle. The highest sound attenuation found at $45^{\circ}$ louvre blade angle with all different louvred barrier setup. The highest sound attenuation achieved when $30 \mathrm{~mm}$ thickness of mineral wool used. Even though sound attenuation was the highest measured, computational fluid dynamic simulation results showed the highest air flow resistance, which could be a concern building such a noise barrier. Sound attenuation depending on different barrier setup varies between $2 \mathrm{~dB}(\mathrm{~A})$ and $17 \mathrm{~dB}(\mathrm{~A})$ in equivalent broadband sound level. 
2. Sound attenuation increased with blade inclination angle. The highest sound attenuation values got when the blade inclined at $45^{\circ}$ the equivalent sound attenuation was $17 \mathrm{~dB}(\mathrm{~A})$. Barrier setup with mineral wool used most effective from $2500 \mathrm{~Hz}$ to $3150 \mathrm{~Hz}$ octave frequency bands. Depending on the blade inclination angle in those frequencies, attenuation varied from $14 \mathrm{~dB}(\mathrm{~A})$ to $28 \mathrm{~dB}(\mathrm{~A})$.

\section{REFERENCES}

Baltrènas, P., Petraitis, E., \& Januševičius, T. (2010). Noise level study and assessment in the southern part of Panevėžys. Journal of Environmental Engineering and Landscape Management, 18(4), 271-280. https://doi.org/10.3846/jeelm.2010.31

Defrance, J., \& Jean, P. (2003). Integration of the efficiency of noise barrier caps in a $3 \mathrm{D}$ ray tracing method. Case of a T-shaped diffracting device. Applied Acoustics, 64(8), 765-780. https://doi.org/10.1016/S0003-682X(03)00034-3

Dimitrijević, S. M., García-Chocano, V. M., Cervera, F., Roth, E., \& Sánchez-Dehesa, J. (2019). Sound insulation and reflection properties of sonic crystal barrier based on micro-perforated cylinders. Materials, 12(17), 2806.

https://doi.org/10.3390/ma12172806

Duhamel, D. (2006). Shape optimisation of noise barriers using genetic algorithms. Journal of Sound and Vibration, 297(1-2), 432-443. https://doi.org/10.1016/j.jsv.2006.04.004

Engel, Z. (2014). Notes on sound absorption technology, K.U. Ingard. Archives of Acoustics, 21(1), 115-117.

García-Chocano, V. M., \& Sánchez-Dehesa, J. (2013). Optimum control of broadband noise by arrays of cylindrical units made of a recycled material. Applied Acoustics, 74(1), 58-62. https://doi.org/10.1016/j.apacoust.2012.06.008

Gražulevičienè, R., \& Bendokienè, I. (2009). Influence of truck traffic on acoustic pollution in Kaunas districts crossed by highways. Journal of Environmental Engineering and Landscape Management, 17(4), 198-204. https://doi.org/10.3846/1648-6897.2009.17.198-204

International Organization for Standardization. (2010). ISO 10140-2:2010. Acoustics Laboratory measurement of sound insulation of building elements Part 2: Measurement of airborne sound insulation.

Januševičius, T. (2011). Statybinių medžiagų ir konstrukcijų akustiniu savybiu tyrimas ir panaudojimas triukšmui mažinti patalpose (Doctoral dissertation, VGTU leidykla "Technika"). (in Lithuanian)

Lee, J., Chang, J. D., \& Coffeen, R. (2020). Acoustical Evaluations of a Double Skin Façade as a Noise Barrier of a Naturally-Ventilated Facade. Journal of Acoustics, 2(1). https://doi.org/10.20900/joa20200001

Matsumoto, T., Yamamoto, K., \& Kuno, K. (2004). Measurement and rating of sound insulation of absorptive louvers. The Journal of the Acoustical Society 
of Japan, 60(11), 646-654. https://www.icacommission.org/Proceedings/ ICA2004Kyoto/

Monsefi, M., Dehghani, F., \& Vojdani, Z. (2011). Noise exposure of pregnant mice induces heart defects in their fetuses. Toxicological \& Environmental Chemistry, 93(4), 780-788. https://doi.org/10.1080/02772248.2011.552506

Naderzadeh, M., Monazzam, M. R., Nassiri, P., \& Fard, S. M. B. (2011). Application of perforated sheets to improve the efficiency of reactive profiled noise barriers. Applied Acoustics, 72(6), 393-398. https://doi.org/10.1016/j.apacoust.2011.01.002

Radosz, J. (2019). Acoustic performance of noise barrier based on sonic crystals with resonant elements. Applied Acoustics, 155, 492-499. https://doi.org/10.1016/j.apacoust.2019.06.003

Romero-García, V., Sánchez-Pérez, J. V., García-Raffi, L. M., Herrero, J. M., García-Nieto, S., \& Blasco, X. (2009). Hole distribution in phononic crystals: Design and optimization. The Journal of the Acoustical Society of America, 125(6), 3774-3783. https://doi.org/10.1121/1.3126948

Sánchez-Pérez, J. V., Caballero, D., Mártinez-Sala, R., Rubio, C., Sánchez-Dehesa, J., Meseguer, F., Llinares, J., \& Gálvez, F. (1998). Sound attenuation by a two-dimensional array of rigid cylinders. Physical Review Letters, 80(24), 5325. https://doi.org/10.1103/PhysRevLett.80.5325

Umnova, O., Attenborough, K., \& Linton, C. M. (2006). Effects of porous covering on sound attenuation by periodic arrays of cylinders. The Journal of the Acoustical Society of America, 119(1), 278-284. https://doi.org/10.1121/1.2133715

Venckus, Ž., Grubliauskas, R., \& Venslovas, A. (2012). The Research on the Effectiveness of the Inclined Top Type of a Noise Barrier. Journal of Environmental Engineering and Landscape Management, 20(2), 155-162. https://doi.org/10.3846/16486897.2011.634068

Viveiros, E. B., Gibbs, B. M., \& Gerges, S. N. Y. (2002). Measurement of sound insulation of acoustic louvres by an impulse method. Applied Acoustics, 63(12), 1301-1313.

Viveiros, E. B. (1998). Evaluation of the acoustical performance of louvre by impulse response analysis [Universidade Federal de Santa Catarina]. https://repositorio. ufsc.br/handle/123456789/77590

Voropayev, S. I., Ovenden, N. C., Fernando, H. J., \& Donovan, P. R. (2017). Finding optimal geometries for noise barrier tops using scaled experiments. The Journal of the Acoustical Society of America, 141(2), 722-736. https://doi.org/10.1121/1.4974070

Watts, G. R., Hothersall, D. C., \& Horoshenkov, K. V. (2001). Measured and predicted acoustic performance of vertically louvred noise barriers. Applied Acoustics, 62(11), 1287-1311. https://doi.org/10.1016/S0003-682X(00)00101-8

World Health Organization. (2011). Burden of disease from environmental noise: Quantification of healthy life years lost in Europe. World Health Organization. Regional Office for Europe. 
THE BALTIC JOURNAL OF ROAD AND BRIDGE ENGINEERING 2021/16(1)

Yoon, J. Y., \& Pyo, S. (2019). A Review of Mitigation Measures for Reducing Railway Rolling Noise from an Infrastructure Point of View. International Journal of Railway, 12(1), 1-9. https://doi.org/10.7782/ijr.2019.12.1.001

Zavadskas, E. K., Kaklauskas, A., Turskis, Z., \& Kalibatas, D. (2009). An approach to multi-attribute assessment of indoor environment before and after refurbishment of dwellings. Journal of Environmental Engineering and Landscape Management, 17(1), 5-11. https://doi.org/10.3846/1648-6897.2009.17.5-11 